\title{
Seasonal Dispersal of the Oak Wilt Fungus by Colopterus truncatus and Carpophilus sayi in Minnesota
}

\author{
Angie K. Ambourn, Department of Entomology, University of Minnesota, St. Paul 55108; Jennifer Juzwik, USDA \\ Forest Service, North Central Research Station, St. Paul, MN 55108; and Roger D. Moon, Department of Entomol- \\ ogy, University of Minnesota, St. Paul 55108
}

\begin{abstract}
Ambourn, A. K., Juzwik, J., and Moon, R. D. 2005. Seasonal dispersal of the oak wilt fungus by Colopterus truncatus and Carpophilus sayi in Minnesota. Plant Dis. 89:1067-1076.

Sap beetles (Nitidulidae) are considered important overland vectors of the oak wilt pathogen, Ceratocystis fagacearum, in the north central United States. Colopterus truncatus and Carpophilus sayi are thought to be the principal sap beetle vectors in Minnesota. Field studies using windoriented funnel traps baited with aggregation pheromones of the insects were conducted during 2 years in east central Minnesota. The studies compared temporal flight dynamics of Colopterus truncatus and Carpophilus sayi from April through October, measured the proportion of dispersing adults of each species carrying viable pathogen propagules, and estimated the populations of contaminated dispersing beetles in oak (Quercus spp.) stands with and without oak wilt. Abundance of Colopterus truncatus peaked in either April or May, but the pathogen was most frequently isolated ( 20 to $45 \%$ ) from beetles obtained from oak wilt sites from July through September. However, the highest contaminated insect population (CIP) generally occurred during April and May. Abundance of Carpophilus sayi peaked in October of both years, but the pathogen was most commonly isolated from beetles collected during May and June. The CIP was highest in June. The infective insect potential, as indexed by CIP, was greatest for both species in the spring and was greater for Colopterus truncatus than for Carpophilus sayi.
\end{abstract}

Additional keywords: fungal phoresy rates, vascular wilt disease

Oak wilt, caused by Ceratocystis fagacearum (Bretz) Hunt, is spread overland by insect vectors such as sap beetles (Coleoptera: Nitidulidae) (15). Insect transmission is significant because it is the means by which new oak wilt infection centers are established. Sap beetles transmit infectious propagules from the pathogen's sporulating mats formed on recently killed oaks (Quercus spp.) to fresh wounds on healthy oaks $(8,16,21,23,26)$.

Many species of sap beetles have been associated with the oak wilt disease cycle. Based on his review of the literature, Skalbeck (27) reported 27 different species

Corresponding author: J. Juzwik

E-mail: jjuzwik@fs.fed.us

Current address of A. Ambourn: USDA Forest Service, Forest Health Protection, 3700 Airport Way, Fairbanks, AK 99709.

Mention of a trademark, proprietary product, or vendor does not constitute a guarantee or warranty of the product by the USDA, and does not imply its approval to the exclusion of other products or vendors that may also be suitable.

Accepted for publication 6 June 2005.

DOI: 10.1094/PD-89-1067

This article is in the public domain and not copyrightable. It may be freely reprinted with customary crediting of the source. The American Phytopathological Society, 2005. associated with oak wilt fungal mats and 38 different species attracted to wounds on oaks. However, little distinction has been made as to the relative importance of species-specific vectors in pathogen transmission (25). Norris (26), however, suggested that some species might have a greater ecological specialization in their association with the pathogen than others. Sap beetle species dispersing in oak wilt centers, the species associated with fungal mats, and the frequency with which each carried viable propagules of the pathogen were studied in Minnesota in the early 1980s (18). Glischrochilus quadrisignatus Olivier, G. fasciatus Say, G. sanguinolentus Olivier, and G. siepmanni Brown were the most commonly captured free-flying nitidulid species (in descending order of frequency) trapped in dough- and melonbaited traps. Colopterus truncatus Randall was the most common species present in oak wilt mats, and Glischrochilus, Epuraea, Colopterus, and Carpophilus species were contaminated with $C$. $f a$ gacearum (17).

Further studies were conducted in Minnesota to test the hypothesis that all sap beetles that have been implicated as $C$. fagacearum vectors are important in the pathogen's transmission in nature (5). Colopterus truncatus and Carpophilus sayi Parsons were found to account for $54 \%$ of the 2,542 nitidulid beetles collected from fungal mats. Fungal isolations revealed these two species also were carrying high numbers of viable propagules $(>3,000$ CFU per beetle) (5). Colopterus truncatus and Carpophilus sayi also were found to account for $95 \%$ of all sap beetles attracted to fresh wounds in a subsequent study $(20,21)$. Furthermore, $78 \%$ of the beetles were contaminated with the pathogen. Thus, these two species are currently considered the principal sap beetle vectors of C. fagacearum during spring in Minnesota.

Studies were undertaken in 2002 to learn more about the temporal flight dynamics of Colopterus truncatus and Carpophilus sayi throughout the growing season in Minnesota. Such knowledge could lead to new control methods for overland transmission or lead to refinements of existing guidelines for disease prevention. New light also may be shed on the relative importance of each species in spreading the pathogen. New quantitative information could be useful in developing models to predict seasonal risks associated with the infective insect potential for $C$. $f a$ gacearum by specific insects. In order to accomplish this, the time of year when $C$. fagacearum-contaminated beetles are dispersing in oak wilt stands must be identified, as well as any differences in vectoring potential that may exist between the species.

Temporal flight dynamics of Colopterus truncatus have been studied in Minnesota to some extent. Peak abundance of this species has been shown to occur in early spring $(22,27)$. There has been some characterization of Carpophilus sayi flight activity in Wisconsin (23); however, temporal flight dynamics for Carpophilus sayi in Minnesota have not been determined. Difference in occurrences of Colopterus truncatus and Carpophilus sayi in wounds and mats has been documented. In Iowa, Norris (26) showed Colopterus truncatus arrives in the mats earlier than Carpophilus sayi and colonizes younger mats. Colopterus truncatus also was more abundant than Carpophilus sayi in "infectable" wounds.

Field studies were initiated in east central Minnesota to compare and contrast Colopterus truncatus and Carpophilus sayi in relation to the oak wilt disease cycle. Specific objectives were to: (i) determine the abundance of dispersing Colopterus truncatus and Carpophilus sayi over the 
growing season in oak stands with and tion of the dispersing beetles of each species contaminated with $C$. fagacearum, and (iii) estimate the contaminated beetle populations in sampled stands as a measure of the infective insect potential of each species during spring, summer, and fall.

\section{MATERIALS AND METHODS}

Study sites. Beetle populations were studied at six oak stands near the Minneapolis/St. Paul, MN, metropolitan area in 2002 and 2003. Selected stands included oak wilt sites with coalescing infection centers at Carlos Avery Wildlife Management Area, Washington County; and a privately owned woodlot in Columbus Township, Anoka County. Non-oak wilt sites included a privately owned woodlot in Lake Elmo, Washington County; and a privately owned woodlot in Pine Springs, Washington County. Two additional sites (one oak wilt and one non-oak wilt) were studied in 2003 in the southern part of the Minneapolis/St. Paul metropolitan area at Murphy-Hanrehan Park, Scott County.

Abundance of beetles. Carpophilus sayi and Colopterus truncatus were captured with wind-oriented funnel traps (10). Traps were placed approximately $1.5 \mathrm{~m}$ above the ground and $10 \mathrm{~m}$ apart. The common collection vial on each trap contained loosely packed, shredded paper without oak wilt, (ii) determine the propor-

intended to reduce the possibility of crosscontamination (of pathogen propagules) among captured insects. Baits used for the Colopterus truncatus traps in 2002 and 2003 consisted of a high dose $(3.5,500$, and $280 \mu \mathrm{g}$ of components 1, 2, and 3, respectively) of the Colopterus truncatus pheromone (Great Lakes IPM, Vestaburg, $\mathrm{MI}$ ) and $10 \mathrm{ml}$ of viscous, fermenting whole wheat bread dough (22). Two Colopterus truncatus traps were placed at each site. Baits used for the Carpophilus sayi traps in 2002 were according to Bartelt et al. (4), where the species was captured in four different types of traps. These included high-dose (55 and $450 \mu \mathrm{g}$ of components 3 and 4, respectively) Carpophilus sayi pheromone (Great Lakes IPM) and $10 \mathrm{ml}$ of viscous, fermenting bread dough; low-dose (6 and $45 \mu \mathrm{g}$ of components 3 and 4, respectively) Carpophilus sayi pheromone plus bread dough; high-dose Carpophilus sayi pheromone only; and low-dose Carpophilus sayi pheromone only. Four traps (one of each type) were placed at each site in 2002. Baits used for the Carpophilus sayi traps in 2003 consisted of a high dose (55 and $450 \mu \mathrm{g}$ of components 3 and 4 , respectively) of Carpophilus sayi pheromone (Great Lakes IPM) and $10 \mathrm{ml}$ of viscous, fermenting bread dough. Two such traps were placed at each site in 2003. Traps were emptied and re-baited weekly from

Table 1. Best-fitting models resulting from Poisson regression analyses of significant explanatory variables that affect mean numbers of Colopterus truncatus adults caught in wind-oriented funnel traps in oak wilt and non-oak wilt sites in east central Minnesota from April to October 2002 and 2003

\begin{tabular}{|c|c|c|c|c|c|c|}
\hline Year & Variable & Level & Estimate & SE & Wald $\chi^{2}$ & $P$ value \\
\hline \multirow[t]{15}{*}{2002} & Constant & & 1.98 & 0.05 & 43.04 & $<0.0001$ \\
\hline & Month & May & -1.19 & 0.07 & -17.83 & $<0.0001$ \\
\hline & & June & -2.47 & 0.12 & -20.31 & $<0.0001$ \\
\hline & & July & -4.39 & 0.34 & -13.07 & $<0.0001$ \\
\hline & & August & -4.82 & 0.34 & -14.35 & $<0.0001$ \\
\hline & & September & -4.39 & 0.30 & -14.45 & $<0.0001$ \\
\hline & & October & -5.12 & 0.50 & -10.20 & $<0.0001$ \\
\hline & Site type & Non-oak wilt & -2.36 & 0.13 & -17.90 & $<0.0001$ \\
\hline & Sex & Female & -0.09 & 0.05 & -1.75 & $>0.07$ \\
\hline & Interaction & May*site & 1.68 & 0.16 & 10.42 & $<0.0001$ \\
\hline & & June*site & 2.27 & 0.20 & 13.63 & $<0.0001$ \\
\hline & & July*site & 1.77 & 0.57 & 3.09 & $<0.002$ \\
\hline & & August*site & 0.16 & 1.06 & 0.15 & $>0.80$ \\
\hline & & September*site & -8.88 & 50.38 & -0.18 & $>0.80$ \\
\hline & & October*site & 0.97 & 1.13 & 0.87 & $>0.30$ \\
\hline \multirow[t]{15}{*}{2003} & Constant & & 0.53 & 0.10 & 5.26 & $<0.0001$ \\
\hline & Month & May & 1.39 & 0.11 & 13.14 & $<0.0001$ \\
\hline & & June & -0.78 & 0.16 & -4.87 & $<0.0001$ \\
\hline & & July & -0.94 & 0.16 & -6.00 & $<0.0001$ \\
\hline & & August & -0.20 & 0.14 & -1.49 & $>0.10$ \\
\hline & & September & -0.76 & 0.16 & -4.80 & $<0.0001$ \\
\hline & & October & -0.49 & 0.16 & -3.07 & $<0.002$ \\
\hline & Site type & Non-oak wilt & -0.32 & 0.15 & -2.09 & $<0.03$ \\
\hline & Sex & Female & -0.37 & 0.05 & -7.85 & $<0.0001$ \\
\hline & Interaction & May*site & -0.34 & 0.17 & -2.08 & $<0.03$ \\
\hline & & June* site & 0.30 & 0.23 & 1.28 & $>0.10$ \\
\hline & & July*site & -0.45 & 0.27 & -1.71 & $>0.08$ \\
\hline & & August*site & -1.11 & 0.26 & -4.21 & $<0.0001$ \\
\hline & & September*site & -0.01 & 0.25 & -0.05 & $>0.90$ \\
\hline & & October*site & 0.35 & 0.23 & 1.50 & $>0.10$ \\
\hline
\end{tabular}

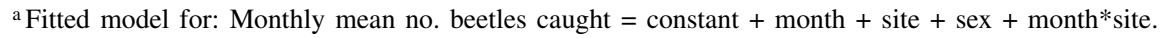
Results of contrasts between levels of the coefficients and the first level (implied to be 0) are presented.
11 April to 18 October 2002, and 10 April to 16 October 2003.

Beetle processing. Adult beetles were removed from traps, identified, their sex determined, and stored individually in sterilized, micro-centrifuge tubes at $-2^{\circ} \mathrm{C}$ until further processed. Representative individuals of each species were deposited in the Insect Museum, Department of Entomology, University of Minnesota, St. Paul, by A. Ambourn. Within 6 months of capture, $0.5 \mathrm{ml}$ of water was added to each dead specimen and homogenized for $5 \mathrm{~s}$ using an ultrasonic tip sonicator to dislodge fungal propagules on the exoskeleton and in the gut. The resulting solution was then serially diluted (10-, 100-, and 1,000 -fold), and $0.5-\mathrm{ml}$ aliquots of each dilution were spread onto triplicate lactic acid-amended potato dextrose agar (PDA) plates, for a total of nine plates per beetle. The number of $C$. fagacearum colonies was recorded 10 days after the plates had been incubated at $24^{\circ} \mathrm{C}$ in the dark (5). Colony appearance and asexual spore characteristics were used to identify $C$. fagacearum (3).

Statistical analyses. Counts of Colopterus truncatus and Carpophilus sayi obtained in the traps were analyzed using Poisson regression in ARC (6). Results from each year were analyzed separately because variances were different between years. For each year, counts of beetles caught in wind-oriented funnel traps were the response variables, and site type (oak wilt versus non-oak wilt), month, sex, and all two-way interactions were the predictor variables. The most parsimonious model was obtained through backward elimination, which sequentially removed inconsequential terms based on the Mallows $C_{I}$ statistic (6). The significance of each remaining term was interpreted using the Wald $\chi^{2}$ test.

Fitted mean beetle counts per site for each species and sex by month and site type were obtained from the Poisson regression analysis table data function. These values were used for graphing beetle temporal flight dynamics over the course of the study. Standard errors for the fit means were calculated as

$$
\mathrm{SE}=\sqrt{\frac{\bar{x}}{n}}
$$

because in a Poisson distribution the mean is assumed to be equal to the variance (6).

Presence of $C$. fagacearum propagules on, or in, Colopterus truncatus and Carpophilus sayi was analyzed using binomial regression (6). Each specimen was scored as 0 if propagules were absent, or 1 if present. Results for each species and year were analyzed separately, with initial model terms for site, month, sex, and all two-way interactions. Again, backward elimination was used to obtain the most parsimonious model (6). 
The proportion of $C$. fagacearumcontaminated beetles by species and sex for each sampling month and site type was determined by dividing the number of beetles testing positive for $C$. $f a$ gacearum by the total number of beetles tested. The standard error for the proportion contaminated was calculated using

$$
\mathrm{SE}=\sqrt{\frac{p(1-p)}{n}}
$$

as per Esker and Nutter (12), where $p$ is the proportion of samples positive, $1-p$ is the proportion of samples negative, and $n$ is the total number of Carpophilus sayi or Colopterus truncatus tested.

To combine trap catches with levels of contamination, the contaminated insect population (CIP) was calculated for male and female Colopterus truncatus and Carpophilus sayi for each month and year. CIP is an estimation of the population of presumably infective insects (i.e., those having the ability to effect the transmission of a pathogen), and was indexed by the product of the fitted monthly beetle catches per site and the corresponding proportions that were contaminated (12). The standard error for CIP was calculated according to Freese (13).

\section{RESULTS}

Seasonal abundance of Colopterus truncatus. In 2002, results of Poisson regression indicated that numbers of captured beetles varied across months $(P<$ $0.0001)$ and by site type $(P<0.0001)$ (Table 1). Beetle catches were highest in April (Fig. 1). Catches in oak wilt sites were greater than in non-oak wilt sites (Table 1). Overall, abundance trends in both site types decreased as the season progressed (Fig. 2A and B), but they differed slightly, as indicated by the difference in site $x$ month interaction for April through July ( $P$ $<0.01$, Table 1). There was no difference in mean number of males and females trapped; terms for sex and all other twoway interactions were not significant $(P>$ 0.1 ). Abundance of Colopterus truncatus in 2002 exhibited a unimodal pattern (Fig. $2 \mathrm{~A}$ and $\mathrm{B})$. Peak flight occurred in the week of 18 April, when 599 insects were trapped. Over the entire year, 97\% $(N=$ $1,461)$ of the specimens were trapped between 18 April and 30 June. The sex ratio was 1.0:1.1 females to males $(N=1,461)$.

In 2003, results of Poisson regression indicated that catches varied by month $(P$ $<0.0001$, except August, $P>0.1$ ), across sites $(P<0.03)$, and by sex $(P<0.0001)$ (Table 1). Catches in oak wilt sites were greater than in non-oak wilt sites (Fig. 1).
Catches of males were greater than of females, except in oak wilt sites in August. Overall abundance increased sharply in May (Fig. 2C and D), decreased, and then leveled off, except in August and October, as indicated by the site $\times$ month interaction. All other two-way interactions were not significant $(P>0.1)$. Patterns of abundance in 2003 were different from that observed in 2002 (Fig. 2C and D). Peak flight occurred in the week of 1 May, when 356 insects were caught. Over the entire year, $74 \%(N=1,814)$ of all specimens were caught between 17 April and 26 June. In 2003, there was a second peak in the week of 21 August $(N=86)$ and a third peak in the week of 9 October $(N=76)$.

The sex ratio was 1.0:1.5 females to males $(N=1,814)$.

Seasonal abundance of Carpophilus sayi. In 2002, results of Poisson regression indicated that number of beetles captured varied across months $(P<0.002)$ and by site type $(P<0.0001)$ (Table 2$)$. Catches of the beetles were lowest in April (Fig. 1). Catches were greater in non-oak wilt sites than in oak wilt sites (Table 2). Overall, abundance increased from April to July, decreased in August and September, and increased sharply in October (Fig. 3A and $B)$. Sex and all two-way interactions were not significant $(P>0.07)$. Peak flight oc-

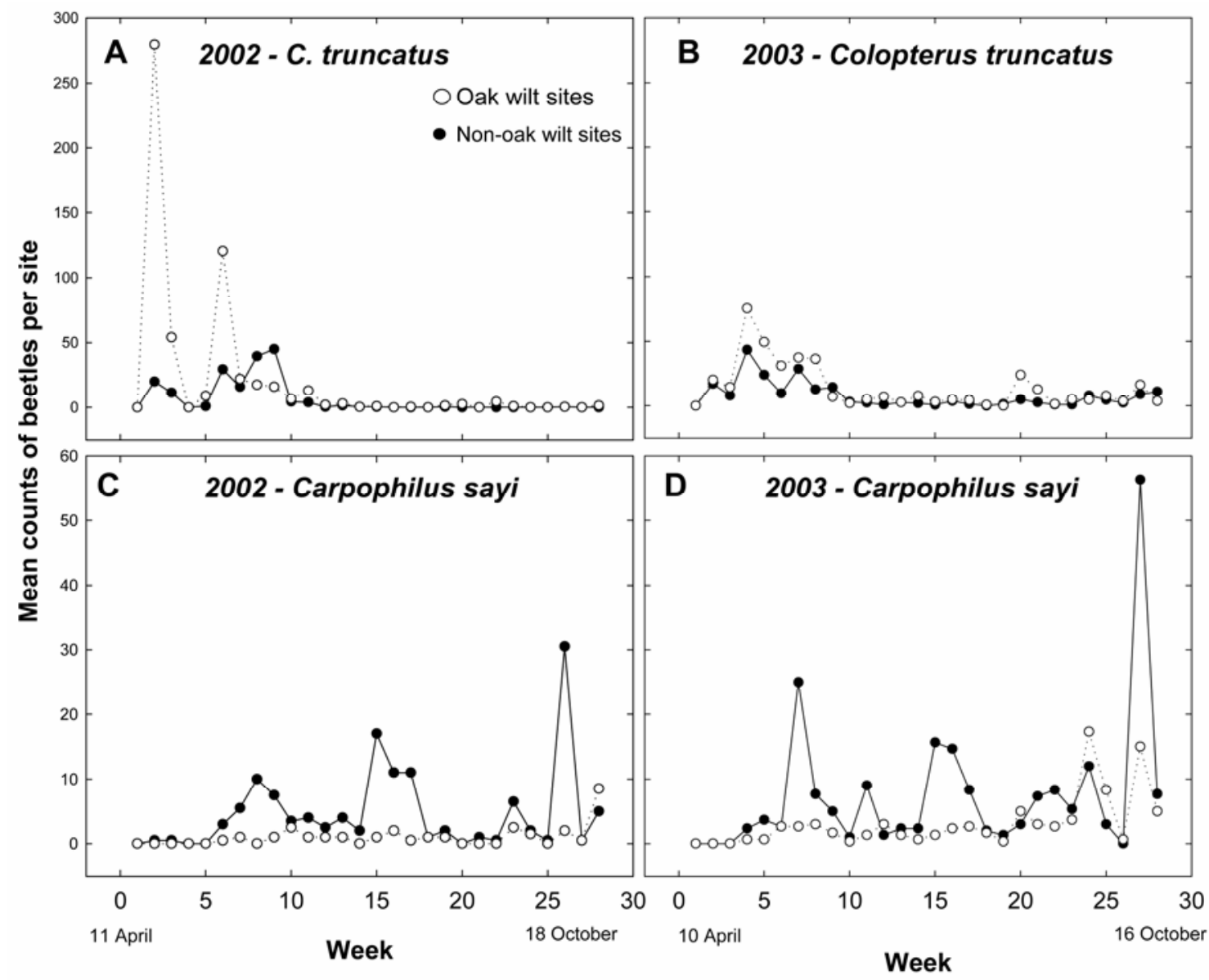

Fig. 1. Mean numbers of Colopterus truncatus (A and B) and Carpophilus sayi (C and D) captured each week in four sites, by year and site type. Insects were caught in wind-oriented funnel traps using species-specific pheromones from April to October in east central Minnesota. 
curred in the week of 4 October, when 68 insects were captured (Fig. 1). Two other very small peaks occurred in the week of 20 May $(N=20)$ and in the week of 18 July $(N=36)$. Over the entire season, $58 \%$ $(N=320)$ of the specimens were captured between 16 May and 1 August. The sex ratio was $1.0: 1.0$ females to males $(N=$ 319).

In 2003, results of Poisson regression indicated that catches were greater in nonoak wilt sites than in oak wilt sites $(P<$ 0.0001) (Table 2). Overall abundance increased as the season progressed (Fig. 1, Fig. 3C and D). Terms for month, sex, and all two-way interactions were not significant $(P>0.1)$. Patterns of abundance in 2003 were similar to those observed in 2002 , but more insects were caught overall. The highest number of beetles $(N=$ 214) was captured during the week of 9 October (Fig. 1). Interestingly, 163 of the specimens were caught in one trap. Three other very small peaks were found the weeks beginning 22 May $(N=83), 24$ July $(N=51)$, and 18 September $(N=88)$. Over the entire season, $44 \%(N=887)$ of all specimens were caught between 1 May and 7 August. The sex ratio was 1.1:1 $(N=887)$.

Contamination by $C$. fagacearum. In 2002, results of binomial regressions indicated the presence of $C$. fagacearum on Colopterus truncatus varied across months $(P<0.03$, except July and October, $P>$ $0.8)$, by site type $(P<0.002)$, and by sex $(P<0.006)$ (Table 3). May, June, August, and September had higher proportions of individuals with $C$. fagacearum propagules than were present in April. The proportion of individuals contaminated with $C$. $f a$ gacearum in oak wilt sites was greater than in non-oak wilt sites. Finally, a higher proportion of males were carrying $C$. $f a$ gacearum propagules than females. No two-way interactions were significant $(P>$ 0.8 ). The proportion of Colopterus truncatus carrying viable propagules of $\mathrm{C}$. $\mathrm{fa}$ gacearum in 2002 ranged from 0.00 to 0.63 (Table 4). For beetles yielding $C$. fagacearum, the average CFU per beetle ranged from 6 to 1,800 (Table 4).

The proportions of Colopterus truncatus carrying $C$. fagacearum in 2003 varied across sites $(P<0.0001)$ (Table 3$)$. Greater proportions of individuals were carrying $C$. fagacearum propagules in the oak wilt sites than in non-oak wilt sites $(P<$ $0.0001)$. Terms for month, sex, and twoway interactions were not significant $(P>$ 0.1 ). The proportion of Colopterus truncatus carrying C. fagacearum in 2003 ranged from 0.07 to 0.46 (Table 4). For beetles yielding $C$. fagacearum, the average $\mathrm{CFU}$ per beetle ranged from 55 to 28,000 .

Results of binomial regressions for 2002 data indicated contamination rates for

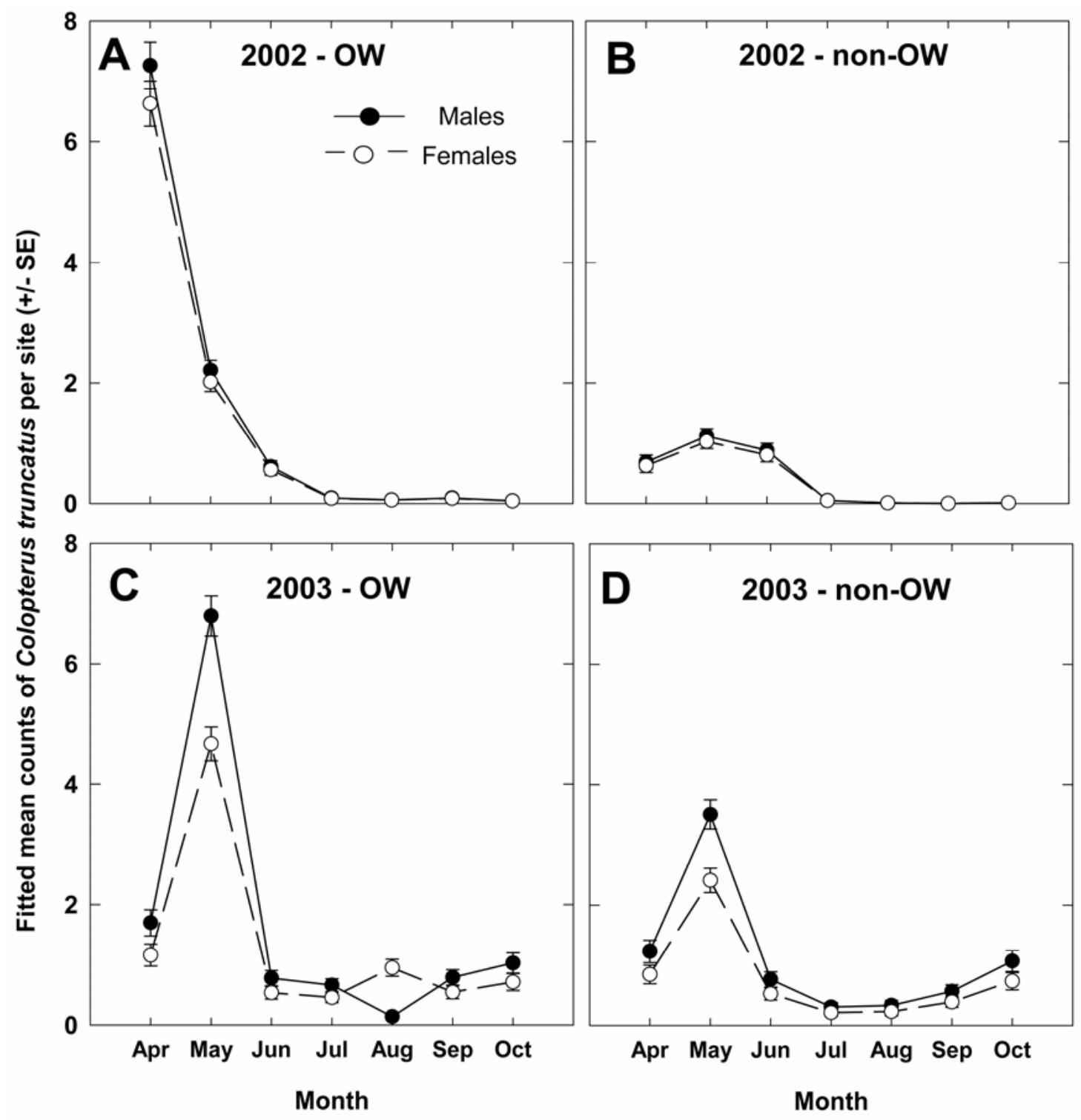

Fig. 2. Fitted mean counts per site \pm SE for Colopterus truncatus males (closed circle/solid line) and females (open circle/dashed line) captured per month in four sites, by year and site type (oak wilt, A, 2002 and C, 2003, or non-oak wilt, B, 2002 and D, 2003). Insects were caught in wind-oriented funnel traps using species-specific pheromones from April to October in east central Minnesota. 
Table 2. Best-fitting models resulting from Poisson regression analyses of significant explanatory variables that affect mean numbers of Carpophilus sayi adults caught in wind-oriented funnel traps in oak wilt and non-oak wilt sites in east central Minnesota from April to October 2002 and $2003^{\mathrm{a}}$

\begin{tabular}{|c|c|c|c|c|c|c|}
\hline Year & Variable & Level & Estimate & SE & Wald $\chi^{2}$ & $P$ value \\
\hline \multirow[t]{8}{*}{2002} & Constant & & -5.60 & 0.72 & -7.82 & $<0.0001$ \\
\hline & Month & May & 2.48 & 0.73 & 3.44 & $<0.0006$ \\
\hline & & June & 2.85 & 0.72 & 3.95 & $<0.0001$ \\
\hline & & July & 3.56 & 0.71 & 4.98 & $<0.0001$ \\
\hline & & August & 2.35 & 0.73 & 3.24 & $<0.0012$ \\
\hline & & September & 2.31 & 0.73 & 3.17 & $<0.0015$ \\
\hline & & October & 3.85 & 0.71 & 5.40 & $<0.0001$ \\
\hline & Site type & Non-oak wilt & 1.53 & 0.15 & 10.47 & $<0.0001$ \\
\hline \multirow[t]{8}{*}{2003} & Constant & & -14.04 & 43.38 & -0.32 & $>0.70$ \\
\hline & Month & May & 13.06 & 43.38 & 0.30 & $>0.70$ \\
\hline & & June & 12.47 & 43.38 & 0.29 & $>0.70$ \\
\hline & & July & 13.07 & 43.38 & 0.30 & $>0.70$ \\
\hline & & August & 12.52 & 43.38 & 0.29 & $>0.70$ \\
\hline & & September & 13.46 & 43.38 & 0.31 & $>0.70$ \\
\hline & & October & 14.08 & 43.38 & 0.03 & $>0.70$ \\
\hline & Site type & Non-oak wilt & 0.87 & 0.72 & 11.78 & $<0.0001$ \\
\hline
\end{tabular}

${ }^{a}$ Fitted model for: Monthly mean no. beetles caught $=$ constant + month + site + sex + month $*$ site. Results of contrasts between levels of the coefficients and the first level (implied to be 0) are presented.
Carpophilus sayi did not differ among months $(P>0.9)$, by site type $(P>0.9)$, or by sex $(P>0.6)$ (Table 5$)$. The proportion of Carpophilus sayi carrying viable propagules of $C$. fagacearum in 2002 ranged from 0.06 to 0.25 (Table 6). For beetles yielding $C$. fagacearum, the average CFU per beetle ranged from 21 to 17,000 .

In 2003, results of binomial regression indicated contamination levels on Carpophilus sayi varied across months $(P<0.02$, except August, $P>0.8)$, among sites $(P<$ $0.0001)$, and between sexes $(P<0.03)$ (Table 5). The proportion of individuals carrying C. fagacearum in all months except June was less than in May. The proportion contaminated was greater in oak wilt sites than in non-oak wilt sites, and more females were carrying fungal propagules than males. No two-way interactions were significant $(P>0.1)$. The proportion of beetles contaminated with $C$. fagacearum in 2003 ranged from 0 to

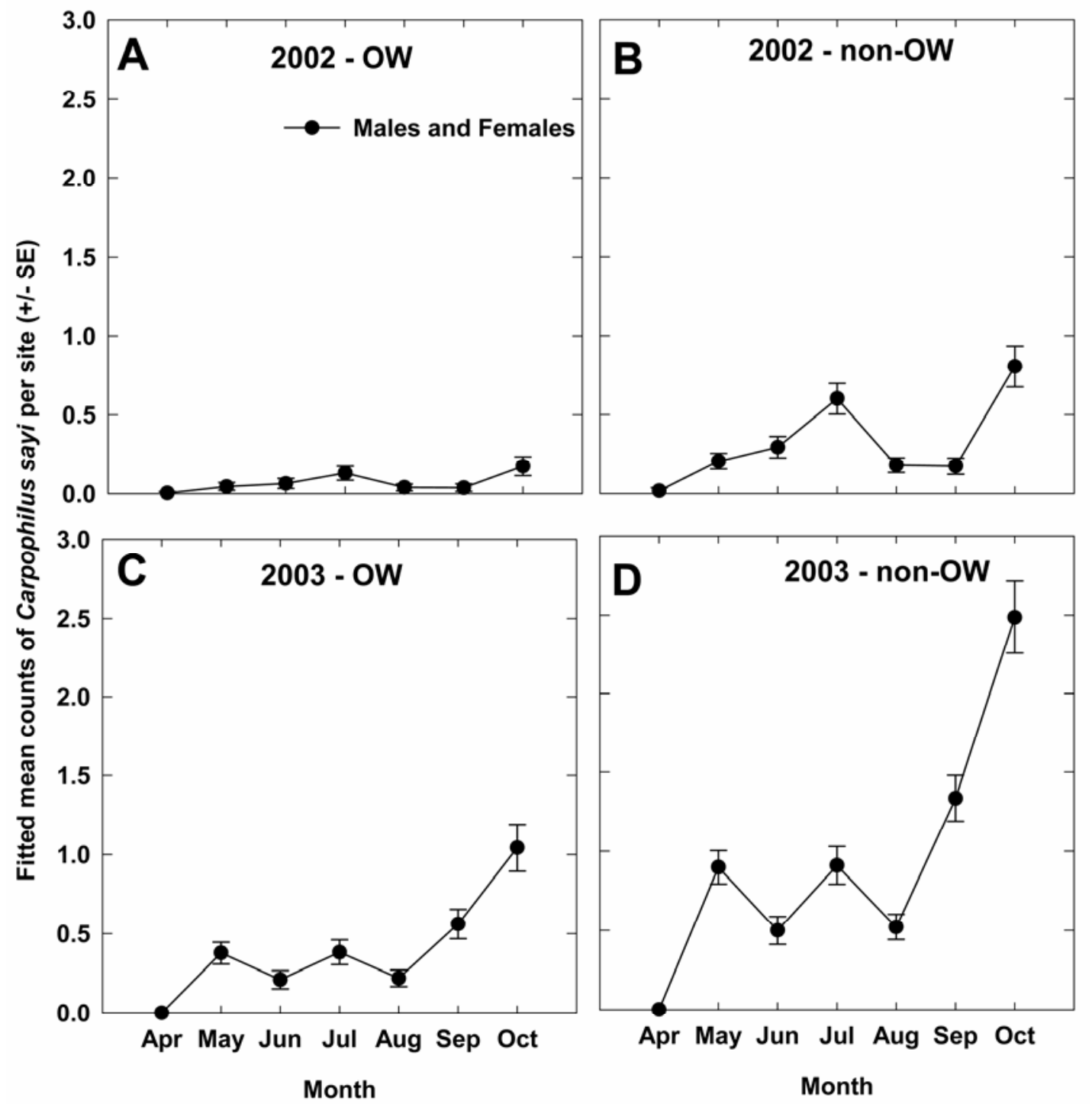

Fig. 3. Fitted mean counts per site \pm SE for Carpophilus sayi, sexes combined, captured per month in four sites, by year and site (oak wilt, A, 2002 and $\mathbf{C}$, 2003, or non-oak wilt, B, 2002 and D, 2003). Insects were caught in wind-oriented funnel traps using species-specific pheromones from April to October in east central Minnesota. 
0.833 (Table 6). For beetles yielding $C$. fagacearum, the average CFU per beetle ranged from 9 to 43,000 .

Contaminated insect populations. Contaminated insect populations (CIP) for Colopterus truncatus in 2002 were greatest in April, May, and/or June in both site types (Fig. 4A and B). Peak CIP occurred in oak wilt sites in April (approximately 0.6 infective beetles per trap). Colopterus truncatus males represented a higher CIP than females in the oak wilt sites in April and May (Fig. 4A). In the non-oak wilt sites, there was little difference between males and females (Fig. 4B).

In 2003, male and female Colopterus truncatus CIP was similar to levels observed in 2002 (Fig. 4C and D). Peak CIP occurred in the oak wilt sites in May (ap- proximately 1.3 infective beetles per trap), and the overall CIP decreased as the season progressed. Contaminated insect populations were highest in May and June, then decreased and leveled off through September and October when a slight peak occurred (Fig. 4D). In both site types, the CIPs for males were slightly greater than for females.

Contaminated insect populations for Carpophilus sayi in 2002 were very low (Fig. 5A and B). Peak CIP occurred in the non-oak wilt sites in June (approximately 0.08 infective beetles per trap) (Fig. 5B). In general, CIP decreased after June and then increased again in October. Overall, the CIP of females was slightly higher than for males in both oak wilt and non-oak wilt sites.

Table 3. Best-fitting models resulting from binomial regression analyses of significant explanatory variables that affect presence of Ceratocystis fagacearum propagules on Colopterus truncatus adults caught in wind-oriented funnel traps in oak wilt and non-oak wilt sites in east central Minnesota from April to October 2002 and $2003^{a}$

\begin{tabular}{|c|c|c|c|c|c|c|}
\hline Year & Variable & Level & Estimate & SE & Wald $\chi^{2}$ & $P$ value \\
\hline \multirow[t]{9}{*}{002} & Constant & & -3.60 & 0.30 & -12.10 & $<0.0001$ \\
\hline & Month & May & 1.19 & 0.31 & 3.86 & $<0.0001$ \\
\hline & & June & 2.33 & 0.33 & 7.03 & $<0.0001$ \\
\hline & & July & -7.65 & 42.82 & -0.18 & $>0.80$ \\
\hline & & August & 1.85 & 0.84 & 2.20 & $<0.03$ \\
\hline & & September & 2.95 & 0.66 & 4.44 & $<0.0001$ \\
\hline & & October & -7.82 & 80.42 & -0.10 & $>0.90$ \\
\hline & Site type & Non-oak wilt & -0.91 & 0.28 & -3.24 & $<0.002$ \\
\hline & Sex & Males & 0.64 & 0.23 & 2.77 & $<0.006$ \\
\hline \multirow[t]{9}{*}{2003} & Constant & & -13.70 & 54.10 & -0.25 & $>0.80$ \\
\hline & Month & May & 12.65 & 54.10 & 0.23 & $>0.80$ \\
\hline & & June & 12.96 & 54.10 & 0.24 & $>0.80$ \\
\hline & & July & 12.80 & 54.10 & 0.24 & $>0.80$ \\
\hline & & August & -0.12 & 365.60 & 0.00 & $>0.90$ \\
\hline & & September & 0.14 & 125.40 & 0.001 & $>0.90$ \\
\hline & & October & 10.93 & 54.10 & 0.20 & $>0.80$ \\
\hline & Site type & Non-oak wilt & -1.29 & 0.20 & -6.59 & $<0.0001$ \\
\hline & Sex & Males & -0.02 & 0.15 & -1.40 & $>0.10$ \\
\hline
\end{tabular}

a Fitted model for: Probability of isolating fungus $=$ constant + month + site + sex. Results of contrasts between levels of the coefficients and the first level (implied to be 0 ) are presented.

In 2003, the CIPs for Carpophilus sayi were different than in 2002 (Fig. 5C and D). Peak CIP in oak wilt and non-oak wilt sites occurred in June (approximately 0.16 and 0.07 infective beetles per trap, respectively). Overall, CIP increased until June, declined through July and August, and increased again in September and October in oak wilt sites. In general, CIP of males was higher in the spring than for females, but dropped off sharply as the season progressed. Contaminated insect population of females was higher than of males in July, September, and October.

For both Colopterus truncatus and Carpophilus sayi, CIP estimations of zero were either due to no beetles being trapped in a given month (as in September 2002 for Colopterus truncatus, Fig. 3A and B) or to the fact that no beetles yielded $C$. fagacearum upon isolation (as in all other cases).

\section{DISCUSSION}

Highest numbers of Colopterus truncatus dispersing in oak stands occurred in early to mid-spring of both years, with numbers decreasing as the growing season progressed. This time of peak abundance coincided with the historical "critical spring period" for overland transmission of C. fagacearum to healthy oaks in Minnesota (14). The peak also was consistent with results of Kyhl et al. (22) in which $98 \%$ of similarly trapped Colopterus truncatus were found between mid-April and mid-June. A major spring flight peak followed by a smaller fall peak as was seen in this study was reported for Colopterus truncatus in several previous studies in Illinois, Minnesota, and Wisconsin $(7,11,19,23,27)$.

In contrast, the highest numbers of Carpophilus sayi were caught in October of both years. In general, abundance of this

Table 4. Ceratocystis fagacearum (Cf) contamination proportions and CFU from male and female adult Colopterus truncatus resulting from serial dilution plating assays in 2002 and 2003

\begin{tabular}{|c|c|c|c|c|c|c|c|c|c|c|}
\hline \multirow[b]{2}{*}{ Year } & \multirow[b]{2}{*}{ Site type } & \multirow[b]{2}{*}{ Month } & \multicolumn{4}{|c|}{ Males } & \multicolumn{4}{|c|}{ Females } \\
\hline & & & $\begin{array}{c}\text { No. } \\
\text { assayed }\end{array}$ & $\begin{array}{c}\text { No. } \\
\text { positive }\end{array}$ & $\begin{array}{c}\text { Proportion } \\
\text { with Cf }\end{array}$ & $\begin{array}{l}\text { Mean CFU/ } \\
\text { beetle } \pm \text { SE }^{\mathrm{a}}\end{array}$ & $\begin{array}{c}\text { No. } \\
\text { assayed }\end{array}$ & $\begin{array}{c}\text { No. } \\
\text { positive }\end{array}$ & $\begin{array}{l}\text { Proportion } \\
\text { with Cf }\end{array}$ & $\begin{array}{l}\text { Mean CFU/ } \\
\text { beetle } \pm \text { SE }\end{array}$ \\
\hline \multirow[t]{7}{*}{2002} & \multirow[t]{5}{*}{ Oak wilt ${ }^{\mathrm{b}}$} & April & 204 & 16 & 0.08 & $390 \pm 250$ & 192 & 0 & 0.00 & $\ldots^{c}$ \\
\hline & & May & 147 & 20 & 0.14 & $280 \pm 150$ & 129 & 11 & 0.09 & $710 \pm 510$ \\
\hline & & June & 41 & 11 & 0.27 & $200 \pm 150$ & 48 & 14 & 0.29 & $510 \pm 230$ \\
\hline & & August & 6 & 1 & 0.17 & $55 \pm 55$ & 3 & 1 & 0.33 & $250 \pm 250$ \\
\hline & & September & 8 & 5 & 0.63 & $1,800 \pm 950$ & 3 & 0 & 0.00 & 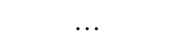 \\
\hline & \multirow[t]{2}{*}{ Non-oak wilt ${ }^{\mathrm{d}}$} & May & 90 & 7 & 0.08 & $89 \pm 71$ & 63 & 2 & 0.03 & $6 \pm 5$ \\
\hline & & June & 31 & 3 & 0.10 & $43 \pm 29$ & 46 & 7 & 0.15 & $60 \pm 32$ \\
\hline \multirow[t]{6}{*}{2003} & \multirow[t]{3}{*}{ Oak wilt $\mathrm{e}^{\mathrm{e}}$} & May & 399 & 80 & 0.20 & $2,400 \pm 1,200$ & 260 & 75 & 0.29 & $5,700 \pm 2,500$ \\
\hline & & June & 24 & 11 & 0.46 & $28,000 \pm 19,000$ & 41 & 10 & 0.24 & $89 \pm 97$ \\
\hline & & July & 12 & 4 & 0.33 & $2,300 \pm 1,600$ & 9 & 3 & 0.33 & $770 \pm 730$ \\
\hline & \multirow[t]{3}{*}{ Non-oak wilt ${ }^{\mathrm{f}}$} & May & 195 & 15 & 0.08 & $1,800 \pm 1,700$ & 155 & 12 & 0.0 & $2,300 \pm 2,100$ \\
\hline & & June & 34 & 4 & 0.12 & $55 \pm 29$ & 16 & 1 & 0.06 & $160 \pm 160$ \\
\hline & & October & 42 & 3 & 0.07 & $233 \pm 230$ & 15 & 0 & 0.00 & $\ldots$ \\
\hline
\end{tabular}

${ }^{a} \mathrm{CFU}$ of $C$. fagacearum counted on potato dextrose agar following the 10-day incubation period after serial dilution plating.

${ }^{\mathrm{b}}$ In July, 5 males and 4 females were assayed; none were positive. In October, 2 males and 1 female were assayed; none were positive.

${ }^{\mathrm{c}}$ Calculation not applicable.

${ }^{\mathrm{d}}$ In April, 28 males and 25 females were assayed; none were positive. July to October, only 7 males were assayed; none were positive.

e In April, 71 males and 39 females were assayed; none were positive. August to October, 35 males and 28 females were assayed; none were positive.

${ }^{\mathrm{f}}$ In April, 47 males and 20 females were assayed; none were positive. July to September, 25 males and 13 females were assayed; none were positive. 
species increased as the growing season progressed, with several distinct peaks occurring during the summer months. This is the first published data on Carpophilus sayi based on adults caught in pheromonebaited flight traps. Flight periods were previously reported for Carpophilus sayi caught in banana-baited traps in Wisconsin (23). In that study, the highest numbers of beetles were caught in May, late July, and mid-September.

Differences in biology, life history, and temporal flight dynamics of these two species may be responsible for varying numbers of beetles in the baited flight traps. Skalbeck (27) showed a progressive arrival of nitidulid species in fungus-baited traps over the growing season in Minnesota. Colopterus truncatus was one of the Carpophilus species did not appear until a week or more later. Skalbeck (27) sugfirst species present in the spring, whereas

gested that differences in capture rates of the two species of beetles at a given site may be affected by differences in type of overwintering site, developmental stage that overwinters, and the amount of heat that is absorbed by developmental substrate of overwintering sites in the spring.

The abundance of Colopterus truncatus and Carpophilus sayi in oak wilt-affected stands can be measured in at least three different situations: those dispersing through the stand, those in fresh wounds on healthy trees, and those in oak wilt fungal mats. In this study, dispersing beetles were measured using pheromone-food synergist bait traps not located on live or dead oak trees. These captured beetles may have come from outside the stand, or may have departed recently from aging oak wilt mats or wounds on trees in the stand. The arrival and departure of beetles from fresh wounds and mats have been documented

Table 5. Best-fitting models resulting from binomial regression analyses of significant explanatory variables that affect presence of Ceratocystis fagacearum propagules on Carpophilus sayi adults caught in wind-oriented funnel traps in oak wilt and non-oak wilt sites in east central Minnesota from April to October 2002 and $2003^{a}$

\begin{tabular}{lllrrrl}
\hline Year & Variable & Level & Estimate & SE & Wald $\boldsymbol{\chi}^{\mathbf{2}}$ & $\boldsymbol{P}$ value \\
\hline 2002 & Constant & & -14.23 & 520.55 & -0.03 & $>0.90$ \\
& Month & May & 0.11 & 535.17 & 0.00 & $>0.90$ \\
& & June & 13.23 & 520.54 & 0.03 & $>0.90$ \\
& & July & 0.18 & 527.61 & 0.00 & $>0.90$ \\
& & August & 0.21 & 534.77 & 0.00 & $>0.90$ \\
& & September & 0.18 & 539.43 & 0.00 & $>0.90$ \\
& October & 9.80 & 520.55 & 0.02 & $>0.90$ \\
& Site type & Non-oak wilt & 0.03 & 0.89 & 0.04 & $>0.90$ \\
Sex & Males & -0.33 & 0.68 & -0.49 & $>0.90$ \\
Constant & & -1.40 & 0.48 & -2.95 & $<0.003$ \\
& Month & June & -1.75 & 0.54 & 3.23 & $<0.001$ \\
& & July & -2.5 & 1.08 & -2.33 & $<0.02$ \\
& & August & -11.44 & 53.12 & -0.02 & $>0.80$ \\
& September & -2.64 & 0.70 & -3.79 & $<0.0002$ \\
& Site type & October & -2.86 & 0.81 & -3.54 & $<0.0004$ \\
& Non-oak wilt & -3.09 & 0.52 & -5.98 & $<0.0001$ \\
& Males & 0.98 & 0.47 & 2.10 & $<0.03$ \\
\hline
\end{tabular}

a Fitted model for: Probability of isolating fungus $=$ constant + month + site + sex. Results of contrasts between levels of the coefficients and the first level (implied to be 0 ) are presented.
$(5,21,26)$. Cease and Juzwik (5) reported Colopterus truncatus as the most abundant species on immature and mature mats in mid- to late May, but the species' presence was much reduced on aging mats during the same time period. Carpophilus sayi was present only in low numbers on the immature and mature mats, but accounted for approximately one-third of the total nitidulid beetles on aging and declining mats. J. F. Kyhl (unpublished) also found differences in adult nitidulid beetles species and their abundances on mats between spring and fall.

Temporal differences in sap beetle species occurrence also have been reported for wounds. In West Virginia, Dorsey and Leach (9) found the highest numbers of sap beetle species in wounds in May and early June; none were found in wounds in July. Norris (26) found Colopterus truncatus was most abundant in $<2$-week-old wounds in Iowa during April, May, and June; Carpophilus sayi also was present during this same time period. In a Minnesota spring wounding study, $>95 \%$ of sap beetles collected from $<6$-day-old wounds were Colopterus truncatus and Carpophilus sayi (21). Very few beetles were collected in April and June; the majority were collected in May. McMullen et al. (24) found both Colopterus truncatus and Carpophilus sayi common in 1-week-old axe blaze wounds on oaks from the end of May through June in Wisconsin.

For beetles collected during spring in this study, the proportions of beetles contaminated with $C$. fagacearum were the highest in June. However, the highest contamination rates for Colopterus truncatus were found for the September $(45 \%)$ and July $(33 \%)$ collections. The pathogen also was isolated from Carpophilus sayi trapped in July, September, and October, but at a low rate $(<5 \%)$. The high isolation frequency for Colopterus truncatus trapped during summer months could be

Table 6. Ceratocystis fagacearum (Cf) contamination proportions and CFU from male and female adult Carpophilus sayi resulting from serial dilution plating assays in 2002 and 2003

\begin{tabular}{|c|c|c|c|c|c|c|c|c|c|c|}
\hline \multirow[b]{2}{*}{ Year } & \multirow[b]{2}{*}{ Site type } & \multirow[b]{2}{*}{ Month } & \multicolumn{4}{|c|}{ Males } & \multicolumn{4}{|c|}{ Females } \\
\hline & & & $\begin{array}{c}\text { No. } \\
\text { assayed }\end{array}$ & $\begin{array}{c}\text { No. } \\
\text { positive }\end{array}$ & $\begin{array}{c}\text { Proportion } \\
\text { with } \mathbf{C f}\end{array}$ & $\begin{array}{l}\text { Mean CFU/ } \\
\text { beetle } \pm \mathrm{SE}^{\mathrm{a}}\end{array}$ & $\begin{array}{c}\text { No. } \\
\text { assayed }\end{array}$ & $\begin{array}{c}\text { No. } \\
\text { positive }\end{array}$ & $\begin{array}{l}\text { Proportion } \\
\text { with Cf }\end{array}$ & $\begin{array}{l}\text { Mean CFU/ } \\
\text { beetle } \pm \text { SE }\end{array}$ \\
\hline \multirow[t]{3}{*}{2002} & Oak wilt ${ }^{b}$ & June & 2 & 0 & 0.00 & $\ldots^{c}$ & 5 & 1 & 0.20 & $66 \pm 66$ \\
\hline & & October & 6 & 0 & 0.00 & $\ldots$ & 16 & 1 & 0.06 & $21 \pm 21$ \\
\hline & Non-oak wilt ${ }^{\mathrm{d}}$ & June & 20 & 5 & 0.25 & $17,000 \pm 10,000$ & 18 & 5 & 0.27 & $5,300 \pm 5,200$ \\
\hline \multirow[t]{7}{*}{2003} & Oak wilt ${ }^{\mathrm{e}}$ & May & 14 & 3 & 0.21 & $290 \pm 240$ & 15 & 2 & 0.13 & $250 \pm 250$ \\
\hline & & June & 6 & 5 & 0.83 & $5,700 \pm 2,600$ & 8 & 6 & 0.75 & $43,000 \pm 4,000$ \\
\hline & & July & 14 & 0 & 0.00 & $\ldots$ & 10 & 1 & 0.1 & $4,000 \pm 4,000$ \\
\hline & & September & 52 & 0 & 0.00 & $\ldots$ & 44 & 3 & 0.07 & $30 \pm 18$ \\
\hline & & October & 23 & 0 & 0.00 & $\ldots$ & 41 & 1 & 0.02 & $9 \pm 8$ \\
\hline & Non-oak wilt ${ }^{\mathrm{f}}$ & May & 51 & 2 & 0.39 & $66 \pm 65$ & 60 & 2 & 0.03 & $48 \pm 33$ \\
\hline & & June & 25 & 0 & 0.00 & $\ldots$ & 25 & 4 & 0.16 & $1,300 \pm 1,100$ \\
\hline
\end{tabular}

${ }^{a} \mathrm{CFU}$ of $C$. fagacearum counted on potato dextrose agar following the 10-day incubation period after serial dilution plating.

${ }^{\mathrm{b}}$ No beetles were assayed in April or May. July to September, 7 males and 13 females were assayed; none were positive.

${ }^{\mathrm{c}}$ Calculation not applicable.

${ }^{\mathrm{d}}$ In April and May, 13 males and 24 females were assayed; none were positive. July to October, 101 males and 86 females were assayed; none were positive.

${ }^{\mathrm{e}}$ In April, no beetles were assayed. In August, 12 males and 13 females were assayed; none were positive.

${ }^{\mathrm{f}}$ In April, no beetles were assayed. July to October, 210 males and 210 females were assayed; none were positive. 
misleading, however, because of the relatively low numbers of adults collected $(N=$ 41, July to September) compared with the spring months ( $N=2,115$, April to June). If one assumes that the pheromone baits for Carpophilus sayi and Colopterus truncatus are equally efficient in attracting beetles of the same species, the threat or infective insect potential posed by these $C$. fagacearum-contaminated beetles to healthy oaks over the growing season is perhaps better expressed by the CIP value.

Proportions of contaminated beetles differed between sites with oak wilt and those without, and is likely attributable to the presence or absence of oak wilt mats (i.e., sites of propagule acquisition by beetles) in the sampled stands. It is interesting that even when sap beetle adults were collected directly from oak wilt mats, the frequency of isolation of the pathogen from the beetles was not necessarily $100 \%$. For example, of 57 Colopterus truncatus collected from mats between 1 April and 27 May,
94\% were contaminated, while only $33 \%$ of mat-inhabiting Carpophilus sayi were contaminated (18). Cease and Juzwik (5) recovered C. fagacearum from Colopterus truncatus less frequently than from five other species (including Carpophilus sayi) that accounted for $94 \%$ of all beetles on oak wilt mats in May. Thus, not all Colopterus truncatus and Carpophilus sayi exiting oak wilt mats are necessarily contaminated. Proportions of $C$. fagacearumcontaminated beetles in wounds on healthy oaks in a stand with active oak wilt in May also were high (84\% for Colopterus truncatus and $71 \%$ for Carpophilus sayi) (21).

The proportions of dispersing sap beetles contaminated with C. fagacearum in this study were much higher than reported previously. Dispersing beetles trapped and assayed in Texas in the mid-1980s $(1,2)$ and earlier in Minnesota in the late 1970s and 1980s $(18,19)$ were collected from fruit or fungus culture, and/or fermenting flour dough-baited traps. For example, only $0.65 \%$ of the 4,126 sap beetles in Texas (trapped October to May) and $0.67 \%$ of the 1,043 sap beetles in Minnesota (trapped March to June) yielded $C$. $f a-$ gacearum. This difference may be attributable to the use of aggregation pheromones specific to the beetle species and closely related species.

The temporal flight dynamics of dispersing Colopterus truncatus and Carpophilus sayi during the spring in stands with active oak wilt and the proportions found to be contaminated with $C$. fagacearum further support the current thought that these two species are the principal sap beetle vectors of the pathogen in Minnesota. Differences in flight dynamics also suggest that Colopterus truncatus may be relatively more important than Carpophilus sayi in this role. Furthermore, higher proportions of contaminated beetles and higher CIP values were found for Colopterus truncatus than for Carpophilus sayi in this study. These results, in turn, suggest

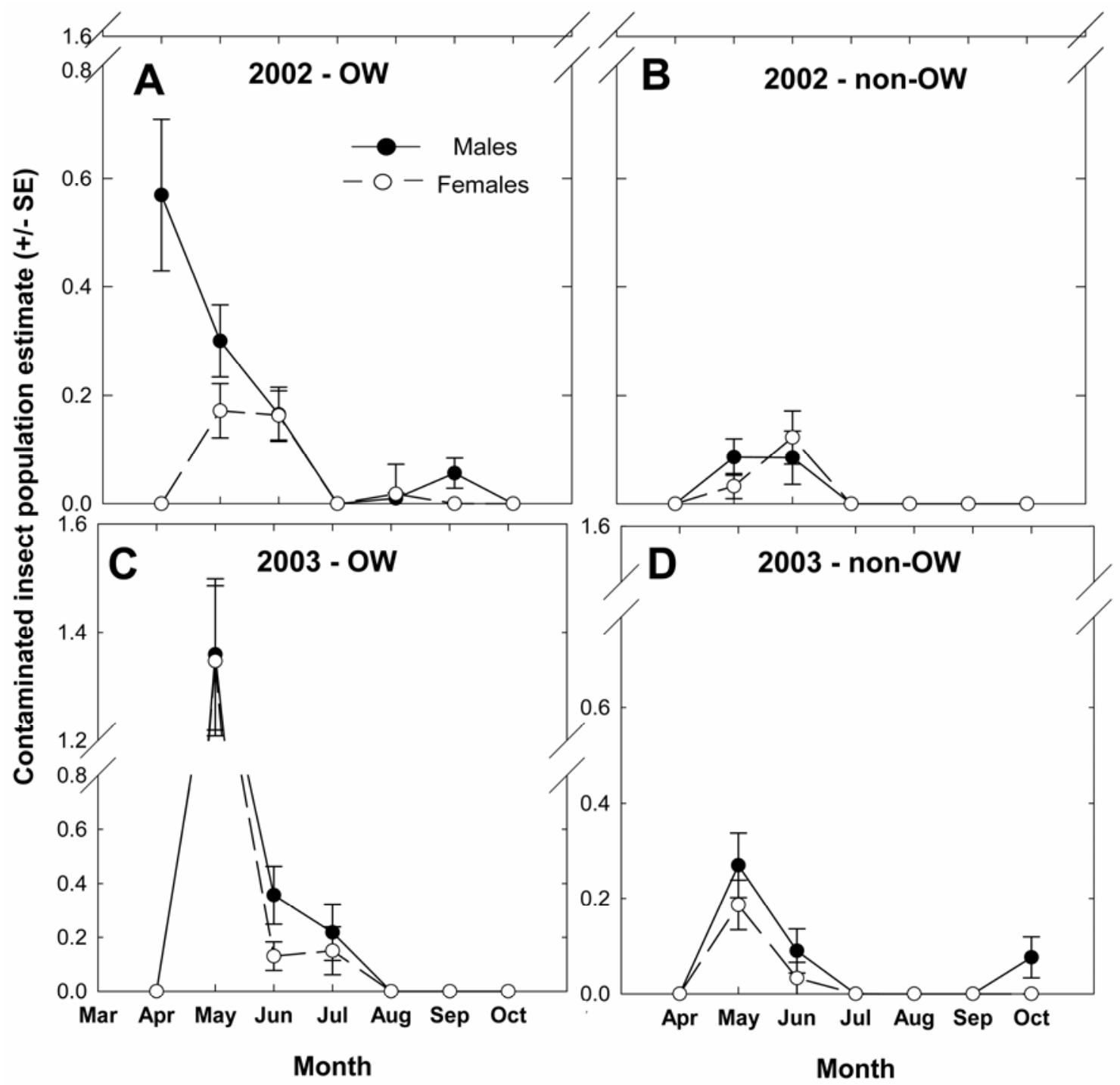

Fig. 4. Contaminated insect population estimates for male and female Colopterus truncatus (determined by multiplying the monthly fit mean per site $\times$ the proportion of individual insects that tested positive for Ceratocystis fagacearum) for four sites by year and site type (oak wilt, A, 2002 and C, 2003, or nonoak wilt, B, 2002 and D, 2003). Insects were trapped in wind-oriented funnel traps using species-specific pheromones from April to October in east central Minnesota. 
that the infective insect potential is greater for Colopterus truncatus than for Carpophilus sayi, particularly during spring months. Based on his studies of numerous insect species associated with oak wilt mats and "infectable wounds" on oaks in Iowa, Norris (26) also concluded Colopterus truncatus is likely the most important sap beetle vector in that state, although quantitative analysis was not used to reach his conclusion.

As previously indicated, CIP proved useful in our study to compare relative importance of two implicated sap beetle vector species. It also may prove useful in comparing two different vector groups, such as oak bark beetles (Coleoptera: Scolytidae) to sap beetles. Additional factors, (e.g., environmental variables and amount of inoculum present) could be added to a risk model and tested for making such comparisons.

Current oak wilt management guidelines in Minnesota include rating the risk of oak wilt transmission potential by month during the year (14). The guidelines specify that pruning, wounding, or felling of oaks during the high-risk period (April to June) should be avoided, while the summer months are considered to be a low-risk period, and late fall and winter are considered "safe" for such actions. Although dispersing Colopterus truncatus and Carpophilus sayi were contaminated with $C$. fagacearum during summer and fall months, the CIP values were relatively low. However, CIP values were higher during the spring months. Thus, relative risk in terms of infective insect potential agrees with previously published guidelines. The attractiveness of fresh summer and fall wounds to Colopterus truncatus and Carpophilus sayi is not clear. Future studies will address the relative attractiveness of fresh summer and fall wounds to sap beetles, and to Colopterus truncatus and Carpophilus sayi in particular. If C. fagacea- rum-contaminated beetles are found in fresh wounds during these seasons, the risk designation will need to be reassessed.

\section{ACKNOWLEDGMENTS}

We thank Fran Nelson, Vanessa Valdespino, and Wendy Francesconi for laboratory and field assistance; Kathy Ward for statistical analysis assistance; Jordan Eggers for graphics assistance; and Marla Spivak, Steve Katovich, Rob Doudrick, and two anonymous individuals for review of the manuscript. This work is a portion of a thesis by the first author in partial fulfillment of M.S. degree requirements at the University of Minnesota.

\section{LITERATURE CITED}

1. Appel, D. N., Andersen, K., and Lewis, R. 1986. Occurrence of Nitidulid beetles (Coleoptera: Nitidulidae) in Texas oak wilt centers. J. Econ. Entomol. 79:1276-1279.

2. Appel, D. N., Kurdyla, T., and Lewis, R. 1990. Nitidulids as vectors of the oak wilt fungus and other Ceratocystis spp. in Texas. Eur. J. For. Pathol. 20:412-417.

3. Barnett, H. L. 1953. Isolation and identification of the oak wilt fungus. W. Va. Univ. Agric. Exp. Stn. Bull. 359T.

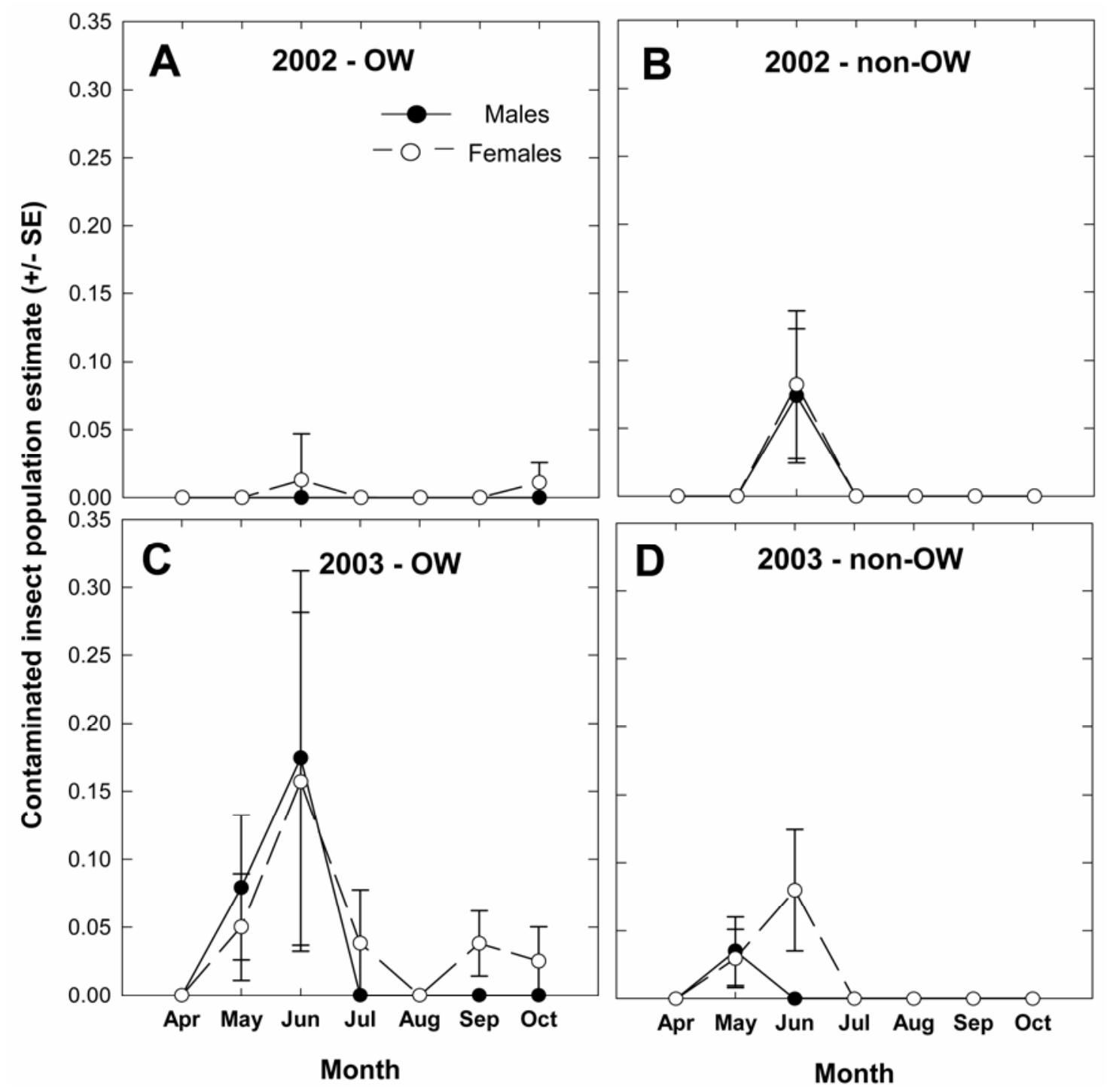

Fig. 5. Contaminated insect population estimates for male and female Carpophilus sayi (determined by multiplying the monthly fit mean per site $\times$ the proportion of individual insects that tested positive for Ceratocystis fagacearum) for four sites by year and site type (oak wilt, A, 2002 and C, 2003, or non-oak wilt, B, 2002 and D, 2003). Insects were caught in wind-oriented funnel traps using species-specific pheromones from April to October in east central Minnesota. 
4. Bartelt, R. J., Kyhl, J. F., Ambourn, A. K., Juzwik, J., and Seybold, S. J. 2004. Maleproduced aggregation pheromone of Carpophilus sayi, a Nitidulid vector of oak wilt disease, and pheromonal comparison with C. lugubris. Agric. For. Entomol. 6:1-8.

5. Cease, K. R., and Juzwik, J. 2001. Predominant nitidulid species (Coleoptera: Nitdulidae) associated with spring oak wilt mats in Minnesota. Can. J. For. Res. 31:635-643.

6. Cook, R. D., and Weisberg, S. 1999. Applied Regression Including Computing and Graphics. John Wiley \& Sons, New York.

7. Cosse, A. A., and Bartlet, R. J. 2000. Male produced aggregation pheromone of Colopterus truncatus: Structure, electrophysiological and behavioral activity. J. Chem. Ecol. 26:1735-1749.

8. Dorsey, C. K., Jewell, F. F., Leach, J. G., and True, R. P. 1953. Experimental transmission of oak wilt by four species of Nitidulidae. Plant Dis. Rep. 37:419-420.

9. Dorsey, C. K., and Leach, J. G. 1956. The bionomics of certain insects associated with oak wilt with particular reference to the Nitidulidae. J. Econ. Entomol. 49:219-230.

10. Dowd, P. F., Bartelt, R. J., and Wicklow, D. T. 1992. Novel insect trap useful in capturing sap beetles (Coleoptera: Nitidulidae) and other flying insects. J. Econ. Entomol. 85:772-778.

11. Dowd, P. F., and Nelsen, T. 1994. Seasonal variation of sap beetle (Coleoptera: Nitidulidae) populations in central Illinois cornfield-oak woodland habitat and potential influence of weather patterns. Popul. Ecol. 23:1215-1223.

12. Esker, P. D., and Nutter, F. W., Jr. 2003. Temporal dynamics of corn flea beetle populations infested with Pantoea stewartii, causal agent of Stewart's Disease of corn. Phytopathology 93:210-218.

13. Freese, F. 1962. Elementary Forest Sampling. U.S. Dep. Agric. Handb. No. 232

14. French, D. W., and Juzwik, J. 1999. Oak Wilt in Minnesota. Univ. Minn. Ext. Serv. Publ. MI3174-GO.

15. Gibbs, J. N., and French, D. W. 1980. The transmission of oak wilt. U.S. Dep. Agric. For. Serv. Res. Pap. NC-185.

16. Himelick, E. B., and Curl, E. A. 1958. Transmission of Ceratocystis fagacearum by insects and mites. Plant Dis. Rep. 42:538-545.

17. Juzwik, J. 1983. Factors affecting overland transmission of Ceratocystis fagacearum in Minnesota. Ph.D. thesis. University of Minnesota, St. Paul.

18. Juzwik, J., and French, D. W. 1983. Ceratocystis fagacearum and $C$. piceae on the surfaces on free-flying and fungus-mat-inhabiting nitidulids. Phytopathology 73:1164-1167.

19. Juzwik, J., and French, D. W. 1986. Relationship between Nitidulids and Ceratocystis fagacearum during late summer and autumn in Minnesota. Plant Dis. 70:424-426.

20. Juzwik, J., Skalbeck, T. C., and Neuman, M. F. 1999. Nitidulids associated with fresh wounds on red oaks during spring in Minnesota.
(Abstr.) Phytopathology 89:S38

21. Juzwik, J., Skalbeck, T. C., and. Neuman, M F. 2004. Sap beetle species (Coleoptera: Nitidulidae) visiting fresh wounds on healthy oaks during spring in Minnesota. For. Sci. 50:757-764.

22. Kyhl, J. F., Bartelt, R. J., Cosse, A. A., Juzwik J., and Seybold, S. J. 2002. Semiochemicalmediated flight response of sap beetle vectors of oak wilt, Ceratocystis fagacearum. J. Chem. Ecol. 28:1527-1547.

23. McMullen, L. H., Drake, C. R., Shenefelt, R. D., and Kuntz, J. E. 1955. Long distance transmission of oak wilt in Wisconsin. Plant Dis. Rep. 39:51-53.

24. McMullen, L. H., Shenefelt, R. D., and Kuntz, J. E. 1960. A study of insect transmission of oak wilt in Wisconsin. Trans. Wisc. Acad. Sci., Arts Lett. 49:73-84.

25. Merrill, W., and French, D. W. 1995. Insects and the epidemiology of oak wilt. Pages 29-39 in: Oak Wilt Perspectives. D. N. Appel and R. F. Billings, eds. Proc. Natl. Oak Wilt Sympos., Texas Agriculture Experiment Station, Texas Forest Service, and Texas Agriculture Extension Service, Austin.

26. Norris, D. M. 1956. Association of insects with the oak tree and Endoconidiophora fagacearum Bretz. Ph.D. thesis. Iowa State University, Ames.

27. Skalbeck, T. C. 1976. The distribution of Nitidulidae in deciduous forests of Minnesota. Ph.D. thesis. University of Minnesota, St. Paul. 